\title{
Efficacy of the entomopathogenic fungus, Metarhizium anisopliae (Metsch.), against larvae of the cotton leafworm, Spodoptera littoralis (Boisd.) (Lepidoptera: Noctuidae), under laboratory conditions
}

\author{
Monir M. M. El Husseini(D)
}

\begin{abstract}
The efficacy of the entomopathogenic fungus, Metarhizium anisopliae, was assessed through applying different conidiospore concentrations of a local isolate against third and fifth larval instars of the cotton leafworm, Spodoptera littoralis (Boisd.) (Lepidoptera: Noctuidae) under laboratory conditions. The lowest tested concentrations $\left(2 \times 10^{1}, 2 \times 10^{2}\right.$, and $2 \times 10^{3}$ conidiospores $\left./ \mathrm{ml}\right)$ caused low mortality rates on the tenth day post-treatment $(2-14 \%$ for $L_{3}$ and $0-6 \%$ for $\left.L_{5}\right)$. The highest concentrations $\left(2 \times 10^{4} 2 \times 10^{5}, 2 \times 10^{6}\right.$, and $2 \times 10^{7}$ conidiospores $\left./ \mathrm{ml}\right)$ induced (52-90\%) mortality rate in $L_{3}$ and (50-100\%) in $L_{5}$ on the seventh day post-treatment. Death of treated larvae started on the fourth day post-treatment with the high concentrations. $L C_{50}$ and $L C_{90}$ values were calculated. They were higher for $L_{3}$ than for $L_{5}$.
\end{abstract}

Keywords: Metarhizium anisopliae, Spodoptera littoralis, Larvae, Efficacy

\section{Background}

The cotton leafworm, Spodoptera littoralis (Boisd.) (Lepidoptera: Noctuidae), is a polyphagous insect pest attacking a wide range of host plants including vegetables and ornamental plants (Rao et al. 1993). In Egypt, it is considered a serious pest on cotton, corn, vegetables, and medicinal and aromatic plants (Amer et al. 2008). Control of this pest was always practiced by applying chemical insecticides. The continuous use of chemical pesticides against this pest resulted in resistant strains to most applied insecticides (Shad et al. 2012 and Gandhi et al. 2016), environmental pollution, and negative impact on non-target insect species like pollinators, insect parasitoids, and predators. Thus, search became urgent for new alternative and environmentally safe biocide agents such as the entomopathogenic fungi (EPF) (Anand et al. 2009). EPFs were used worldwide for

Correspondence: monir.elhusseini@agr.cu.edu.eg;

monirelhusseini45@gmail.com

Centre of Biological Control, Faculty of Agriculture, Cairo University, Giza, Egypt controlling different stages of many insect pests (Liu and Li 2004). They infect insects by penetrating the body, using extracellular cuticle-hydrolyzing enzymes of lipases, proteases, and chitinases (St. Leger et al. 1986). The different isolates of EPFs differ in their efficacy against targeted insect hosts. Petlamul and Prasertsan (2012) related such differences to germination rate, conidia production, radial growth, and enzyme activity.

The present study aimed to test the efficacy of a local isolate of $M$. anisopliae against third and fifth larval instars of the cotton leafworm, S. littoralis, reared on a semi-synthetic diet under laboratory conditions.

\section{Materials and methods}

S. littoralis larvae

A laboratory strain of $S$. littoralis was reared for many generations on the semi-synthetic diet of Shorey and Hale (1965) at $25 \pm 1{ }^{\circ} \mathrm{C}$ and $50-60 \% \mathrm{RH}$ at the Centre of Biological Control, Faculty of Agriculture, Cairo University, Egypt. The prepared diet was poured before solidifying into trays $(20 \times 30 \mathrm{~cm})$ in a layer of $2 \mathrm{~cm}$ in

\section{SpringerOpen}

(c) The Author(s). 2019 Open Access This article is distributed under the terms of the Creative Commons Attribution 4.0 International License (http://creativecommons.org/licenses/by/4.0/), which permits unrestricted use, distribution, and reproduction in any medium, provided you give appropriate credit to the original author(s) and the source, provide a link to the Creative Commons license, and indicate if changes were made. 
thickness. A plastic grid of 80 cubic cells $(2 \times 2 \times 3 \mathrm{~cm})$ was pressed on the diet tray. One larva was confined in each cell on the diet and the structure was covered with a plastic plate perforated with four fine openings over each cell for aeration. The diet amount in each cell is quite enough for the larva to complete development and pupate. The third $\left(\mathrm{L}_{3}\right)$ and fifth $\left(\mathrm{L}_{5}\right)$ larval instars were used for testing the efficacy of $M$. anisopliae isolate.

\section{Propagation of $M$. anisopliae}

A local strain of the fungus originally isolated from a naturally infected mole cricket, Gryllotalpa gryllotalpa L. (El-Husseini et al. 2008) was propagated on Czapek's Dox agar medium. The inoculated plates were incubated for 15 days at $25^{\circ} \mathrm{C}$ and $50-60 \% \mathrm{RH}$. Thereafter, the conidia were harvested from the surface of the cultures by scraping with a sterile solution of $0.01 \%$ Tween-80. The concentration of the resulted stock suspension was estimated, using a hemocytometer and stored in the refrigerator till needed.

\section{Efficacy test}

Seven concentrations of $\left(2 \times 10^{1}, 2 \times 10^{2}, 2 \times 10^{3}, 2 \times 10^{4}\right.$, $2 \times 10^{5}, 2 \times 10^{6}$, and $2 \times 10^{7}$ conidiospore/ml) were prepared in a distilled water from the stock spore suspension. For each tested concentration, 4 replicates, each of 25 larvae in the third and fifth instars were treated by direct spray, using a fine perfume atomizer (El-Husseini et al. 2008). Thereafter, the treated larvae were placed in the cells of the diet trays and left to feed on under a perforated cover plate similarly to those in the rearing technique. For the control, the larvae were sprayed with a distilled water containing $0.01 \%$ Tween 80 and kept on diet as those of the treatments. The mortality rate was recorded daily for 10 days post-treatment. The dead larvae were kept on moistened filter paper in Petri dishes and checked daily for the Green Muscardine symptoms proving the death by $M$. anisopliae.
Table 1 Mortality \% of Spodoptera littoralis $\left(L_{3}\right.$ and $\left.L_{5}\right)$ treated with different concentrations of Metarhizium anisopliae conidiospores

\begin{tabular}{|c|c|c|c|c|c|c|c|c|c|c|c|}
\hline \multirow{2}{*}{$\begin{array}{l}\text { Concentration/ } \\
\mathrm{ml}\end{array}$} & \multirow{2}{*}{$\begin{array}{l}\text { Larval } \\
\text { instar }\end{array}$} & \multicolumn{10}{|c|}{ Mortality $\%$ in days post-treatment } \\
\hline & & 1 & 2 & 3 & 4 & 5 & 6 & 7 & 8 & 9 & 10 \\
\hline \multirow[t]{2}{*}{$2 \times 10^{1}$} & $L_{3}$ & 0 & 0 & 0 & 0 & 0 & 0 & 2 & 2 & 2 & 2 \\
\hline & $\mathrm{L}_{5}$ & 0 & 0 & 0 & 0 & 0 & 0 & 0 & 0 & 0 & 0 \\
\hline \multirow[t]{2}{*}{$2 \times 10^{2}$} & $L_{3}$ & 0 & 0 & 0 & 0 & 4 & 4 & 4 & 4 & 4 & 4 \\
\hline & $\mathrm{L}_{5}$ & 0 & 0 & 0 & 0 & 0 & 0 & 0 & 0 & 0 & 0 \\
\hline \multirow[t]{2}{*}{$2 \times 10^{3}$} & $\mathrm{~L}_{3}$ & 0 & 0 & 0 & 8 & 8 & 10 & 14 & 14 & 14 & 14 \\
\hline & $L_{5}$ & U & 0 & 0 & 2 & 2 & 6 & 6 & 6 & 6 & 6 \\
\hline \multirow[t]{2}{*}{$2 \times 10^{4}$} & $\mathrm{~L}_{3}$ & 0 & 0 & 0 & 16 & 30 & 44 & 52 & 52 & 52 & 52 \\
\hline & $L_{5}$ & 0 & 0 & 0 & 10 & 22 & 30 & 40 & 50 & 60 & 60 \\
\hline \multirow[t]{2}{*}{$2 \times 10^{5}$} & $\mathrm{~L}_{3}$ & 0 & 0 & 0 & 20 & 42 & 58 & 66 & 66 & 66 & 66 \\
\hline & $L_{5}$ & 0 & 0 & 0 & 14 & 38 & 44 & 70 & 70 & 70 & 70 \\
\hline \multirow[t]{2}{*}{$2 \times 10^{6}$} & $L_{3}$ & 0 & 0 & 0 & 38 & 50 & 70 & 88 & 88 & 88 & 88 \\
\hline & $\mathrm{L}_{5}$ & 0 & 0 & 0 & 30 & 46 & 68 & 78 & 78 & 78 & 78 \\
\hline \multirow[t]{2}{*}{$2 \times 10^{7}$} & $L_{3}$ & 0 & 0 & 0 & 44 & 70 & 90 & 90 & 90 & 90 & 90 \\
\hline & $\mathrm{L}_{5}$ & 0 & 0 & 0 & 48 & 92 & 92 & 92 & 100 & & \\
\hline \multirow[t]{2}{*}{ Control } & $\mathrm{L}_{3}$ & 0 & 0 & 0 & 0 & 0 & 0 & 0 & 0 & 0 & 0 \\
\hline & $\mathrm{L}_{5}$ & 0 & 0 & 0 & 0 & 0 & 0 & 0 & 0 & 0 & 0 \\
\hline
\end{tabular}

$L_{3}$ third larval instar, $L_{5}$ fifth larval instar

\section{Statistical analysis}

$\mathrm{LC}_{50}$ and $\mathrm{LC}_{90}$ as well as $\mathrm{LT}_{50}$ and $\mathrm{LT}_{90}$ were calculated, using the software "Ldp Line" software (Bakr 2005). Data were processed by analysis of variance (one-way classification ANOVA), followed by a least significant difference, L.S.D. at 5\% (CoStat statistical software).

\section{Results and discussion}

Beginning from the fourth day post-treatment, death of S. littoralis larvae occurred at the concentration $\left(2 \times 10^{3}\right.$ spores $/ \mathrm{ml}$ ) by 8 and $2 \%$ mortality for $\mathrm{L}_{3}$ and $\mathrm{L}_{5}$, respectively (Table 1$)$. At lower concentrations $\left(2 \times 10^{1}\right.$ and $2 \times$ $10^{2}$ spores $/ \mathrm{ml}$ ), death of $\mathrm{L}_{3}$ larvae started on the seventh and fifth day post-treatment. Meanwhile, no mortality
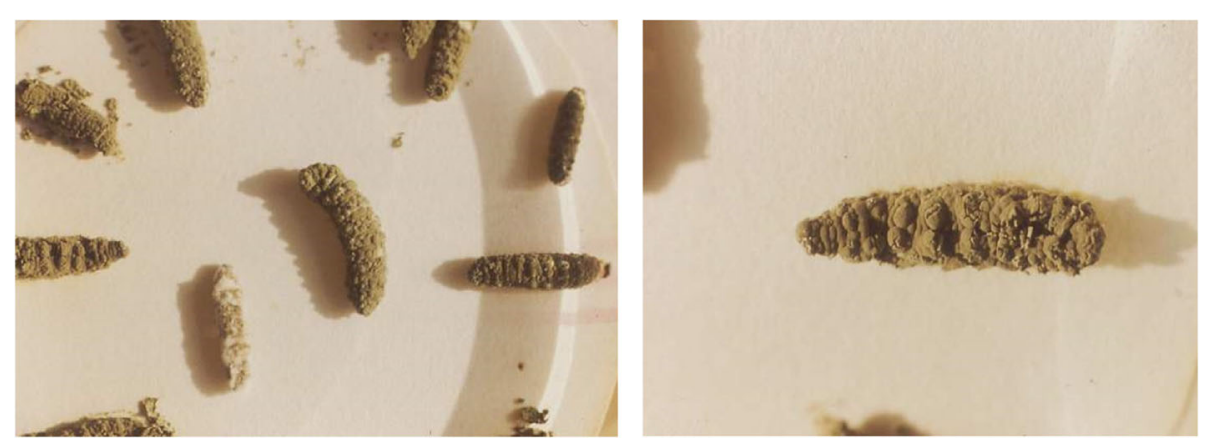

Fig. 1 Cadavers of Spodoptera littoralis larvae covered with the dark green mycelium and spores proving death with Metarhizium anisopliae (Green Muscardine) in the efficacy test 
Table 2 Toxicity of the tested Metarhizium anisopliae isolate against $L_{3}$ and $L_{5}$ larvae of Spodoptera littoralis calculated on seventh day post-treatment

\begin{tabular}{llllll}
\hline Larval instar & $L C$ & Spores $/ \mathrm{ml}$ & Lower limit & Upper limit & Slope \\
\hline $\mathrm{L}_{3}$ & $L C_{50}$ & 62,514 & 7836.7 & $713,797.2$ & 0.5424 \\
& $L C_{90}$ & $14,416,410$ & $9,332,985.6$ & $2,038,922,271.2$ & \\
$L_{5}$ & $L C_{50}$ & 153,515 & $30,408.9$ & $573,999.6$ & 0.6296 \\
& $L C_{90}$ & $16,656,991$ & $6,420,466.7$ & $243,268,447.1$ & \\
\hline
\end{tabular}

appeared among treated $\mathrm{L}_{5}$ larvae with both lower concentrations till the tenth day post-treatment. One hundred percent mortality in $\mathrm{L}_{3}$-treated larvae was not reached till the tenth day of the test, but it was recorded for $\mathrm{L}_{5}$ at the concentration $\left(2 \times 10^{7}\right.$ spores $\left./ \mathrm{ml}\right)$ on the eighth day post-treatment. The present results showed that larval mortality increased by increasing the conidiospores concentrations and that larvae of $\mathrm{L}_{3}$ were more susceptible to the fungus than $\mathrm{L}_{5}$ larvae, especially at the lowest tested concentrations. On the contrary, both instars showed a high mortality rate at the highest concentrations $\left(2 \times 10^{6}\right.$ and $2 \times 10^{7}$ spores $\left./ \mathrm{ml}\right)$ ranging between 88 and $90 \%$ for $L_{3}$ and $78-100 \%$ for $L_{5}$. The infected dead larvae kept under high humidity in Petri dishes developed the typical symptoms for death by $M$. anisopliae known as "Green Muscardine" (Fig. 1).

The calculated $\mathrm{LC}_{50}$ for $\mathrm{L}_{3}$ was 62,514 (slope 0.5424) and 153,515 spores $/ \mathrm{ml}$ (slope 0.6296 ) for $\mathrm{L}_{5}$. Meanwhile, the $\mathrm{LC}_{90 \mathrm{~s}}$ were $14,416,410$ and 16656991 spores $/ \mathrm{ml}$ respectively (Table 2). These results are in line with those of El-Husseini et al. (2008) and Asi et al. (2013).

\section{Conclusion}

The resulted high efficacy (up to $100 \%$ mortality) of the local isolate of the entomopathogenic fungus $M$. anisopliae against third and fifth larval instars of the cotton leafworm $S$. littoralis encourages its use in the IPM programs concerned with this polyphagous pest. Due to its environmental safety to farm animals, $M$. anisolpliae is recommended for controlling the larvae of $S$. littoralis on the Egyptian clover as forage crop lasting nearly 5-6 months in the field and harboring between 3 and 4 generations of $S$. littoralis. Moreover, this forage crop is shadily contributing to protection of the applied fungus spores from the UV. Besides, it provides suitable humidity for the fungus spore germination more than in other host plants of this pest.

Acknowledgements

Not applicable.

Author's contributions

The author wrote, read, and approved the final manuscript.

Funding

This work was not supported by any funding body but personally financed.

\section{Availability of data and materials}

All data are available in the manuscript and the materials used in this work are of high transparency and grade.

Ethics approval and consent to participate

I agree to all concerned regulations.

Consent for publication

I agree to publish this scientific paper in the EJBPC.

Competing interests

The author declares that he has no competing interests.

Received: 3 July 2019 Accepted: 6 August 2019

Published online: 15 August 2019

\section{References}

Amer MM, El-Sayed TI, Bakheit HK, Moustafa SA, El-Sayed YA (2008) Pathogenicity and genetic variability of five entomopathogenic fungi against Spodoptera littoralis. Res J Agric Biol Sci 4:354-367

Anand R, Prasad B, Tiwary BN (2009) Relative susceptibility of Spodoptera litura pupae to selected entomopathogenic fungi. BioControl 54:85-92

Asi MR, Bashir MH, Afzal M, Zia K, Akram M (2013) Potential of entomopathogenic fungi for biocontrol of Spodoptera litura Fabricious (Lepidoptera: Noctuidae). J Animal Plant Sci 23(3):913-918

Bakr EM (2005) A new software for measuring leaf area, and area damaged by Tetranychus urticae Koch. J Appl Entomol 129(3):173-175

El-Husseini MM, Agamy EA, Mesbah AH, El-Fandary OO, Abdallah MF (2008) Using Beauveria bassiana (Bals) Vuillemin in spraying and dusting applications for biological control of sugar beet insect pests in Egypt. Egypt J Biol Pest Control 18(2):369-375

Gandhi K, Patil RH, Srujana Y (2016) Field resistance of Spodoptera litura (Fab.) to conventional insecticides in India. Crop Prot 88:103-108

Liu XZ, Li SD (2004) Fungi secondary metabolites in biological control of crop pests. In: Z.Q (ed) Handbook of Industrial Mycology, An. Marcel Dekker, New York, pp 723-744

Petlamul W, Prasertsan P (2012) Evaluation of strains of Metarhizium anisopliae and Beauveria bassiana against Spodoptera litura on the basis of their virulence, germination rate, conidia production, radial growth and enzyme activity. Microbiology 40(2):111-116

Rao GV, Wightman JA, Rao DV (1993) World review of the natural enemies and diseases of Spodoptera litura (F.) (Lepidoptera: Noctuidae). Insect Sci Appl 14: 273-284

Shad S, Sayyed A, Fazal S, Saleem M, Zaka S, Ali M (2012) Field evolved resistance to carbamates, organophosphates, pyrethroids, and new chemistry insecticides in Spodoptera litura Fab. (Lepidoptera: Noctuidae). J Pest Sci 85: 153-162

Shorey HH, Hale RL (1965) Mass rearing of the larvae of nine noctuid species on a simple artificial medium. J Econ Entomol 58:522-524

St. Leger RJ, Charnley AK, Cooper RM (1986) Cuticle-degrading enzymes of entomopathogenic fungi: mechanisms of interaction between pathogen enzymes and insect cuticle. J Invertebr Pathol 47:295-302

\section{Publisher's Note}

Springer Nature remains neutral with regard to jurisdictional claims in published maps and institutional affiliations. 